\title{
Analysis of sources of return in South African private equity
}

\author{
J.R. van Niekerk and J.D. Krige* \\ University of Stellenbosch Business School, \\ PO Box 610, Bellville 7535, Republic of South Africa \\ jdkrige@sun.ac.za
}

Received March 2009

\begin{abstract}
Private Equity is rapidly growing as an asset class for investors in South Africa. Local and international literature presents overwhelming evidence to suggest that Private Equity offers superior risk-adjusted returns and portfolio diversification benefits.
\end{abstract}

This study addresses the question of how exactly Private Equity managers are able to achieve superior returns. A sample of 46 individual completed investments representing large buy-outs in South Africa in the period 1992 to 2007 was selected and analysed to quantitatively investigate the relationship between some of the identified sources of return and the realised internal rates of return in the case of each investment. These relationships were not found to be as strong as expected and in many cases were not supportive of the findings in the literature. Only earnings growth and an increase in the earnings multiple had a significant impact on the internal rates of return achieved according to the sample analysed.

The authors conclude that investing in Private Equity is too interdisciplinary to distil the sources of return into a few concise elements. Proprietary knowledge, expertise, superior management skills, relationships and experience all seem to play a role in providing Private Equity managers with a competitive edge over their public market participants.

*To whom all correspondence should be addressed.

\section{Introduction}

As enigmatic as the asset class is to many investors, Private Equity is gaining prominence in the South African market at a pace equaled by very few, if any, other asset classes.

At the end of 2007 funds under Private Equity management totaled R86,6 billion. This is equal to $2,8 \%$ of Gross Domestic Product, compared to the international average of $2,1 \%$. Since 1999, funds under management increased at a compound annual growth rate of 14\%. For 2007 South African Private Equity ranked $11^{\text {th }}$ on the global rankings of Private Equity investment activity (KPMG \& SAVCA, 2008). Hence, there is no disputing the relevance of Private Equity as an alternative investment category in South Africa. The strong growth in Private Equity is predominantly spurred by the superior risk-adjusted returns and the portfolio diversification benefits the asset class offers.

Missankov, Van Dyk, Van Biljon, Hayes and Van der Veen (2006) did a comprehensive study of the investment performance of a representative sample set of 11 South African Private Equity funds over a 13-year period. In summarising their findings the authors conclude that, amongst others, Private Equity in South Africa:
- $\quad$ Outperformed the FTSE/JSE All Share Index by $18,0 \%$ per year before fees, and approximately $12,0 \%$ per year after consideration of fees.

- $\quad$ Produced good risk-adjusted performance relative to other asset classes as suggested by calculated Sharpe ratios.

- Displayed low correlation in investment performance with that of other conventional asset classes.

- Offers substantial diversification benefits to portfolios.

Several international studies also suggest that Private Equity delivers superior risk-adjusted returns, although there seems to be a general consensus that the outperformance is lower in larger and more developed markets compared to developing markets.

Given this background, the interesting question to ask is how exactly do Private Equity managers achieve these superior returns? With Private Equity fund managers charging at least $2 \%$ per year on committed capital and a further $20 \%$ of performance in carried interest, an investor would want to be sure of what benefits he or she is actually paying for. Furthermore, if it is possible to distil the sources or attributes of superior performance generated by Private 
Equity fund managers, it will assist in the fund manager selection process and possibly in the culmination of more aligned remuneration schemes for Private Equity fund managers.

The existing pool of knowledge regarding the specific sources of superior returns in Private Equity is limited and opinions vary. Little has been done from a quantitative research perspective.

This study investigates the methods that Private Equity fund managers use to achieve their returns. Sources of return which will be investigated can generally be classified as qualitative or quantitative.

As far as the qualitative factors are concerned, a study of both international as well as local literature is discussed in Section 2. For the quantitative factors, a multiple regression analysis has been done to determine the relevance of each variable in respect of the returns achieved. The data and methodology are reviewed in Section 3, whereas the results are discussed in Section 4. Section 5 concludes the study and makes a number of suggestions for future research.

\section{Literature review of qualitative factors}

While the overwhelming majority of research suggests that Private Equity delivers superior risk-adjusted returns, the research done on the sources of these returns is limited. Some arguments surface repeatedly, while others stand isolated in their opinion. What is evident, however, is the lack of comprehensive academic research which scientifically supports or rejects any of the proposed sources of superior return. This literature review aims to identify and briefly describe as many as possible of the suggested ways Private Equity fund managers use to achieve their returns.

The format of this review will be to discuss the literature related to each of the qualitative factors as a sub-section.

\section{Syndication}

When two or more Private Equity firms mutually take part in an investment opportunity, the situation is referred to as syndication. During 2007, 80\% of the ten largest Private Equity transactions reported in South Africa were done by Private Equity syndicates working together (KPMG \& SAVCA, 2008:31).

Lockett and Wright (2001) identified three rationales for syndicating.

- According to the finance-based rationale, Private Equity firms can reduce the unsystematic risks of their investments by sharing the financial risk. Syndication enables the Private Equity manager to have a more diversified portfolio which results in total risk consisting almost exclusively of systematic risk. Furthermore, Private Equity investments are usually less liquid in nature than those in the stock market. By syndicating, the liquidity risk can be spread on a dealby-deal basis.
- The resource-based rationale has two parts. Firstly, by syndicating, Private Equity firms have access to a larger pool of specialised resources such as financial expertise and market information. This will enable a syndicated team to make a better selection of the companies they decide to invest in, greatly reducing firm-specific risk in the process and enhancing the probability of superior returns. The second part argues that the syndicate can select more experienced and specialised skills from their combined resources in the ex-post management of their investments.

- A third reason is the deal flow rationale. By successfully working together on deals, Private Equity firms increase the likelihood of being asked to participate in future investments by other firms. For firms with a good reputation in syndication, this increases the amount of opportunities to select from for future investments.

A study done by Bent, Williams and Gilbert (2004) on South African Private Equity firms found the reasons for syndication to be consistent with these rationales.

The most important reason for syndication was the large size of the investment relative to the amount of funds available. The second most important reason was the large size of the investment relative to the average investment size of the Private Equity firm. Both of these motivations fall under the finance-based rationale. Increasing future deal flow opportunities was the third most important reason. In the fourth place firms indicated the need to access specific skills, thus the resource-based rationale. A final reason, which is unique to South Africa, is the role of Black Economic Empowerment (BEE) in the drive to syndicate.

The authors concluded that syndicated investments generally have higher rates of return than stand-alone investments, implying that the involvement of multiple firms in the management of the investment is a value adding exercise (Bent et al., 2004:46)

\section{Black Economic Empowerment (BEE)}

The Codes of Good Practice for Broad-Based BEE stipulate the conditions under which the investee company may treat the ownership held by a Private Equity fund as if being held by black people. The requirements under these codes are issued by the Department of Trade and Industry and were finalised in June 2007, providing clarity as to how Private Equity fund managers can further their BEE goals.

BEE continues to play a vital role in South African Private Equity activity (Dada \& Thayser, 2007). Deloitte (2007:5) found that the majority (83\%) of Private Equity investment professionals expect their funds to have some form of BEE ranging from black influence to black control. $80 \%$ of respondents feel that BEE will generate more opportunities for their Private Equity businesses.

Although it is difficult to prove empirically, role players argue that BEE can improve Private Equity returns by: 
- enabling Private Equity fund managers to acquire ownership at a discount to ordinary transactions.

- giving access to more sources of debt at lower prices.

- improving the earnings of the investee company due to better BEE credentials in sectors where BEE companies get preference to do business.

\section{Leverage}

Leverage can be described as the Debt:Equity ratio of the investee company. Private Equity fund managers can decide to alter the leverage of the investee company by selling assets or by refinancing existing assets, amongst others. Most literature sources suggest that leverage is one of the main methods employed by Private Equity fund managers to achieve superior returns (Barber \& Goold, 2007:54; Farzard, Goldstein, Henry \& Palmeri, 2007; Kiechel, 2007:19; Millson \& Ward, 2005:79; Rogers, Holland \& Haas, 2002:98; Missankov et al., 2006:26; Vanek, 2005:9).

Private Equity fund managers' aggressive use of debt and the sale of assets, sometimes referred to as asset-stripping, is criticised by some commentators as being a short-sighted approach and seems to have gathered a negative perception by many outside the industry. However, studies by Deloitte (2007) and Ernst \& Young (2008) state that Private Equity fund managers achieved their returns from a far wider set of inter-disciplinary skills of which increased leverage is merely one of the tools.

The most common method of measuring Private Equity investment returns is by calculating the Internal Rate of Return (IRR) on the money invested by the fund manager. Increased debt can improve this measure in two ways (Fraser-Sampson, 2007). Firstly, debt can be used to acquire ownership in the investee company, hence reducing the amount of own funds used for the same amount of ownership. Secondly, the IRR depends on the timing of the cash flows. The quicker cash is returned to the investor, the higher his IRR. Private Equity fund managers can increase the investee company's debt and use the cash flow for early repayment, increasing IRR in the process.

Another advantage of higher leverage is the tax advantages gained from higher interest expenses (Barber \& Goold, 2007:54).

\section{Valuation multiples}

Two common metrics used in Private Equity are Enterprise Value and Earnings Before Interest, Tax, Depreciation and Amortisation (EBITDA). Consider the following:

Enterprise Value $=$ Market Value of Equity + Net Debt

and

Enterprise Value $=$ EBITDA $\times$ P/EBITDA Multiple
By selling the investment at a higher multiple compared to the multiple at which the investment was made, Private Equity fund managers are able to increase the market value of equity and consequently their returns.

Some proponents argue that the multiple increases achieved by Private Equity fund managers are merely a result of the overall increases experienced in the general market multiples. However, a study done by Ernst \& Young (2008:4) reveals that Enterprise Value for the 100 largest Private Equity exits during 2007 grew at a compound annual growth rate of $24 \%$ compared to the $12 \%$ achieved by public company benchmarks.

On multiple growth, the study (Ernst \& Young, 2008:9) concluded: "More than half of all multiple growth charted for the top exits was attributable to the success of strategies implemented under Private Equity ownership. Strategic repositioning into more attractive areas, a track record of improved profits and cash flows, demonstration of better growth prospects, and contracts to underpin more certain cash flows all contributed to multiple growth. Put simply, after owning them for several years, it is clear that Private Equity investors sold better businesses than they had acquired."

\section{Earnings increase}

The most popular measure of earnings in Private Equity investments is EBITDA (Fraser-Sampson, 2007). Increasing earnings is not an individual action, but rather the result of many different interdependent techniques applied to the investee company. However, the relevant issue, as suggested by the literature (Barber \& Goold, 2007; Ernst \& Young, 2008; Kiechel, 2007; Rogers et al., 2002), is that Private Equity managers tend to increase earnings at a higher rate than their benchmarks.

Ernst \& Young (2008:8) found that the EBITDA compound annual growth rate for 2007 was approximately $16 \%$ for the top 100 Private Equity exits internationally compared with the $10 \%$ achieved by public companies.

By applying their knowledge and skills, Private Equity fund managers can achieve superior returns through superior earnings increases.

\section{Corporate governance}

Corporate governance is increasingly accepted globally as being a very important risk management tool. Research done by Gill (2001) suggests that investors are willing to pay significant premiums for companies that are well-governed. These businesses are typically viewed as being less risky and therefore premiums can be demanded. Millson and Ward (2005:73) confirm that companies with a reputation for good corporate governance have been found to have higher price/earnings multiples and other improved metrics.

Moolenschot (2002) investigated corporate governance in South African Private Equity investments by interviewing 18 Private Equity fund managers. The Private Equity 
investors surveyed all felt that good governance in investee companies was of high importance, and that well governed companies presented better probabilities of successful investment. Private Equity fund managers impose good corporate governance on their investments in their quest for superior returns.

Private Equity representatives who sit on the boards of investee companies place the shareholder at the centre of decision making and act as unsentimental owners who are involved in the hiring and firing of management, and do not hesitate to sell the company when the price is right (Rogers et al., 2002). Private Equity managers consciously strive to avoid corporate governance for corporate governance's sake, but to rather focus on governance which contributes to the sustainable success of the business (Moolenschot, 2002:65).

\section{Management}

Having the right management in investee companies is one of the dominant sources of the superior returns achieved by Private Equity. Barber and Goold (2007:60), Ernst \& Young (2008:12), Millson and Ward (2005:79), Moolenschot (2002:77) and Rogers et al. (2002) found that having appropriate and superior management was a prerequisite for successful investments. Research done by Millson and Ward (2005) on the relevant importance of specific attributes relating to the agent-principal relationship indicates that Private Equity managers are overwhelmingly concerned with the strength of the management team.

Aligning the interests of management and owners is of utmost importance to Private Equity managers. Ernst \& Young (2008:12) suggest that incentives that motivate managers to behave like owners are at the heart of the Private Equity value proposition.

According to Millson and Ward (2005) there are three mechanisms used by Private Equity firms to incentivise the management of their portfolio companies:

- Having relatively large amounts of debt imposes a strong discipline on management and ensures that management treats capital, particularly equity capital, as costly.

- $\quad$ Providing management with significant equity ownership and granting extra equity based on performance.

- Relating management's compensation directly to the performance of the business.

Because all the investments made by Private Equity fund managers are liquidated during the life of the fund, it is easier to measure the precise performance of the investee company and hence easier to tie management incentives directly to company performance (Barber \& Goold, 2007:55).

Apart from having exceptional management in place and aligning the interests of management with that of the owners, Private Equity firms also ensure that returns are generated through the managerial disciplines they impose on their acquired businesses. Rogers et al. (2002) studied more than 2000 Private Equity transactions over a period of ten years and suggest that Private Equity managers mainly apply four managerial disciplines to achieve superior returns:

- $\quad$ They define an investment thesis which is a clear and simple statement of how they will increase business value within three to four years. Every action the company takes is then guided by this investment thesis.

- $\quad$ Private Equity firms are wary of excessive financial measurement and have some general preferences of the measures they track. Cash is monitored more closely than earnings as cash is considered a better indicator of true financial performance. Another preferred measure is return on invested capital rather than other return measures. Management's compensation is then linked directly to these measures.

- Fund managers work the balance sheet by relying heavily on debt financing. In doing so they ensure that cash is viewed as a scarce resource and that equity works harder.

- $\quad$ They adopt a strong shareholder-centric focus. Private Equity corporate staff view themselves as active shareholders in the businesses they hold, obligated to make investment decisions with a complete lack of sentimentality.

\section{Timing}

Timing refers to the endeavour of Private Equity firms to select their timing of investing and timing of selling their investment in such a way as to achieve additional return on investment. As the general market goes through cycles, businesses in general tend to fluctuate in market value as valuation multiples increase and decrease in sympathy with the general market. If Private Equity firms are able to time the market by buying companies when the general valuation is lower and then select to sell at times when the general valuation is higher, timing will be a source of superior return.

Studies indicate that some Private Equity managers do incorporate the technique of timing successfully to a certain extent. In the words of the Ernst \& Young (2008:9) study: "The ability to select favourable exit timing and to be nimble sellers is a source of Private Equity success, as previous studies in this series have found.”

Goldman Sachs Asset Management (2007:1) suggests that during periods of general cyclical down moves of the market, Private Equity firms tend to extend their holding period of portfolio companies in the hope that better future market conditions might provide better exits.

Ernst \& Young (2008:11) differed from this view and found that investee companies with longer holding periods were 
underperforming companies which were given extra time to perform rather than business cycle hostages.

The literature does tend to indicate that Private Equity returns are influenced by market movements. Cochrane (2005), Kaplan and Schoar (2005), and Ljungqvist and Richardson (2003) determined that returns of Private Equity funds appear to be highly correlated with the returns on the market as a whole (Gompers, Kovner, Lerner \& Scharfstein, 2008:2).

Gompers et al. (2008) analysed more than 30000 Private Equity firms over a period of 20 years. They found that there was a definite differentiation of timing-related investment behaviour between experienced and inexperienced Private Equity firms. The greatest response to public market shifts was by specialised Private Equity firms with considerable industry experience. Shifts in public markets provide information to Private Equity firms, but not all firms were able to utilise this information to their advantage and only those firms with superior human capital resources capitalised by using the information for timing purposes.

According to Gompers et al. (2008), firms with less experience also attempted to alter their investment behaviour in response to market cycles, but for these firms it did not translate into superior returns. Experience, industryspecific knowledge and human ability resulted in firms with the most experience to post superior returns by using public market signals as investment opportunities.

\section{Superior knowledge, experience and skill}

Private Equity firms make use of their superior knowledge and skill in two ways in order to increase returns. The first stage is the identification of the investment opportunity and the second phase is the ex-post management of the investee company. Gompers et al. (2008:2) make the observation that the most experienced Private Equity firms generally record the best performance. Kaplan and Schoar (2005:1792) found that underlying heterogeneity in the skill and quality of fund managers leads to differences in performance and also found the persistence of performance to be correlated with the skill and quality of the fund managers.

Fund managers build up relationships and networks over time and through the high level of activity and turnover of invested portfolio companies. They use their extensive networks of business and financial connections, including potential bidding partners, to find new deals (Barber \& Goold, 2007:60). In some cases the investee company might be willing to sell their shares to the Private Equity firm at a lower price purely due to the value they can add by using their networks. Buying companies more cheaply than other role players would certainly contribute to higher returns for Private Equity firms. Ernst \& Young (2008:12) found that during 2007, $82 \%$ of the investments in sample companies were originated proactively through relationships with the investee's management, calls from the fund manager's networks, or company and sector tracking. Many role players argue that, unlike mutual funds or hedge funds,
Private Equity investors have proprietary access to particular transactions (Kaplan \& Schoar, 2005:1792).

After identifying certain possible investments, Private Equity players also display their skill and knowledge through the process of a proper due diligence. Moolenschot's (2002) research confirmed the premium managers place on due diligence in assessing a target company's level of corporate governance. The due diligence done by Private Equity firms reflects a full scope analysis of financial and non-financial issues.

Furthermore, the superior skills and knowledge of the human capital involved as well as the experience gained through the high volume of deals translate into Private Equity firms having the ability to value a company and predict cash flows much more accurately than other investors (Barber \& Goold, 2007:60).

During the ex-post management of the investee company, Private Equity firms once again use their substantial networks and relationships to employ and retain the absolute best managers for achieving their goals.

Gompers et al. (2008:2) summarise the importance of superior knowledge, experience and skill as a source of superior return very well when they assert: "This result points to the importance of industry-specific human capital and suggests that a critical part of venture capital investing is the network of industry contacts to identify good investment opportunities as well as know-how to manage and add value to these investments. These contacts and know-how come only from long standing experience doing deals in an industry."

\section{Public vs private requirements}

Public companies which are listed on exchanges have implicit and explicit requirements that put them at a disadvantage towards Private Equity portfolio companies.

Firstly, the costs related to having and keeping a public company listed on the exchange are high. Private companies avoid these costs.

Secondly, public companies have very stringent reporting requirements. A lot of effort, time and management go into satisfying these requirements. Furthermore, public companies also have the burden of the extremely expensive reporting costs. Deloitte (2007:2) highlights the removal of these costs and requirements as an important aspect in the ability of Private Equity to create value.

Finally, public firms are torn between their long-term goals of creating value and their short-term goals of reporting quarterly to an audience which focuses on short-term financial improvements. Indeed, Rogers et al. (2002) argue that the ability of Private Equity managers to think mediumterm in their portfolio companies gives them a competitive advantage by removing the counterproductive focus on short term numbers and still creating an urgency to transform the business. Out of the public eye, Private Equity firms actually tend to overinvest in businesses during the first six months 
of the investment, positioning the company for growth and enabling them to reap greater rewards later on.

\section{Productivity and cost cutting}

Increased productivity and cost cutting would manifest in increased earnings and hence higher returns. A dominant point of view in the literature is that Private Equity firms have a strong and relentless focus on cutting costs at investee companies. However, they are not constrained when it comes to spending and investing to improve productivity and future growth prospects.

Productivity can be measured as the ratio of production inputs to revenue, profits or other outputs. Private Equity firms generate better returns by increasing the productivity of their portfolio companies and achieving higher productivity levels than public company benchmarks. The Ernst \& Young (2008:2) study found that for 2007, Private Equity investments which were sold had 33\% higher productivity levels than public companies. Private Equity managers increased revenue in their portfolio companies while managing costs and headcount. Even where investee companies clearly added employees, the ratio of EBITDA to headcount mostly improved.

\section{Sources of acquisition}

It can be argued that the sources of acquiring companies for investment lie at the centre of Private Equity's ability to generate superior returns. Returning to the definition of Private Equity, it is evident that a very large difference between this asset class and public companies lies in the fact that most of the companies acquired by Private Equity firms are unlisted, privately owned enterprises. Many private companies do not have the managerial knowledge and skill to perform optimally. They are usually relatively unknown with few objective valuations of the company and are very thinly traded (Anson, 2007:7). Furthermore, if mispricing is present, it will be more significant amongst the illiquid private companies compared to public companies. Private Equity firms use their skills to identify and buy underpriced private companies and then increase the performance of such companies. The ability to generate superior returns might thus also originate from this unique opportunity which few other investors or asset classes have.

Private Equity firms can choose to invest in private companies, public companies which they then take private, or by buying secondary investments from other Private Equity investors.

In analysing the sources of acquisition, Ernst \& Young (2008:7) found that during 2007 private company acquisitions performed best with an Enterprise Value growth of $32 \%$. This was followed by companies bought as secondary investments with an average growth of $27 \%$. Where Private Equity firms bought public companies and took them private, the Enterprise Value growth averaged only $17 \%$. All these figures compare to public company benchmark growth of $12 \%$. It is evident that Private Equity managers can use their unique ability to invest in private companies to achieve superior returns for their investors.

\section{Other sources of return}

The possible sources of return mentioned are the factors which were conspicuous in the literature. However, this by no means implies that the methods Private Equity managers employ to achieve superior returns are limited to these attributes. During the course of the research, the authors also identified other, albeit probably less important, sources of return. These include the positive spin-offs investees might experience from having a new reputable shareholder (Moolenschot, 2002), synergies that different portfolio companies might unlock amongst each other (Barber \& Goold, 2007), effects of controlling ownership, creative financial engineering on the part of fund managers (Boyer \& Baigent, 2008, Goldman Sachs Asset Management, 2008:9), and investing in secondary investments (HarbourVest, 2008:1).

Although the list of origins of Private Equity returns will never be complete, it is important to realise that these factors are seldom independent and mostly interdependent. The question to answer is whether any of these factors can be proven to have a significant impact on the returns achieved by the Private Equity firm on an individual investment basis. This issue is addressed in the following section.

\section{Data and methodology}

The selected sample consists of the completed and exited individual investments made by a number of the largest Private Equity fund managers with the longest track records in South Africa. Due to confidentiality restrictions the identities of the players are withheld. Reliable data about Private Equity investments is extremely difficult to obtain and the authors sincerely hope that the Private Equity industry in South Africa will strive towards greater transparency which will ultimately benefit the industry as a whole in the longer term. The sample contains 54 Private Equity transactions over a period of 15 years. The first transaction was entered into during July 1992 and the last transaction was exited during July 2007.

For each transaction, the following information was received from the Private Equity managers:

- $\quad$ Gross IRR

- Total Investment Cost

- Ownership Percentage

- $\quad$ Enterprise Value at entry

- $\quad$ Percentage Debt at entry

- $\quad$ EBITDA at entry

- $\quad$ Price/EBITDA multiple at entry

- JSE ALSI Price / Earnings (PE) ratio at entry

- $\quad$ Exit date

- Holding Period in years

- $\quad$ Enterprise Value at exit

- $\quad$ EBITDA at exit

- $\quad$ Price/EBITDA multiple at exit

- JSE ALSI PE at exit

All exited investments were included in the data. Investments which were less successful were exited at 
negative IRR's. Hence the authors do not expect the data to suffer from survivorship bias. Where data was incomplete in the sample, that specific investment was omitted from the sample. Due to incomplete data, the sample shrank to 48 investments.

Data was provided by Momentum Wealth and FRAIM (FirstRand Alternative Investment Management) who obtained it from the Private Equity managers. All the data are self-reported by the Private Equity managers. Hence the authors do not take responsibility for any data which might have been calculated incorrectly or reported inaccurately. This is especially relevant regarding the IRR's reported by the managers.

Descriptive statistics were calculated and histograms were constructed for some of the fields to shed more light on the investments and activities of the Private Equity Fund managers. Two definite outliers were found. An investment in the technology sector had an IRR of $573 \%$ p.a. and an investment in the construction sector had an IRR of $620 \%$ p.a. The total investment costs of R13,1 million and R5 million respectively were relatively small compared to the average total investment cost of R72 million. These sample statistics were omitted from the sample to prevent skewing of the results, reducing the data set to 46 cases.

The main part of the analysis concentrates on a multiple regression. Reported IRR's are used as the dependent variable, while the rest of the fields are considered as independent variables.

\section{Multiple regression}

The reported IRR's were regressed with the following independent variables according to ordinary least squares regression:

- Ownership percentage

- Debt percentage

- Holding Period in years

- $\quad$ EBITDA Compound Annual Growth Rate (CAGR) percentage

- $\quad$ Earnings Multiple Value Extraction ratio

- $\quad$ Short-term Interest Rates at Entry

- Total Investment Cost (millions of rand)

- $\quad$ Enterprise Value at Entry

Before doing the regression, scatter plots for the dependent variable and each independent variable were constructed. For each scatter plot a linear trend line was added to determine the nature of the relationship between the independent and dependent variable by visual inspection. Where the relationship was found to be non-linear, a logarithmic trend line was added.
Based on this analysis it was decided to use the natural log of the following independent variables:

- $\quad$ Ownership percentage

- Holding Period in years

- $\quad$ Earnings Multiple Value Extraction ratio

- Total Investment Cost (millions of rand)

- $\quad$ Enterprise Value at Entry

\section{Results}

The regression results are depicted in Table 1.

The resulting regression equation is as follows:

$$
\begin{aligned}
\mathrm{Y}= & 54,72+13,23(\mathrm{LN} \text { Ownership) }-0,15 \text { (Debt) }- \\
& \text { 13,74(LN Holding Period) }+ \text { 0,60(EBITDA CAGR) }+ \\
& \text { 22,26(LN Earnings Multiple Value Extraction) - } \\
& \text { 2,35(ST Interest Rates) }-18,40(\mathrm{LN} \text { Total Investment } \\
& \text { Cost })+10,93(\text { LN Enterprise Value) }
\end{aligned}
$$

According to the Significant $F$ value of almost 0 , at least one of the independent variables explains a significant portion of the variation of the reported IRR's. However, looking at the multiple coefficient of determination, R Squared, only 58\% of the variation in IRR is collectively explained by all of the independent variables. Adjusted R Squared, the coefficient of determination adjusted for the amount of variables, is considerably lower at only $49 \%$. Hence the model as a whole does not have a particularly good fit and the use of the model for predicting IRR's by using the independent variables is limited.

Before testing the statistical significance of each of the coefficients, the model was tested for multicollinearity. This condition distorts the standard error of estimate and the coefficient standard errors, leading to problems when conducting t-tests for statistical significance of parameters (DeFusco, McLeavy, Pinto \& Runkle, 2004). A correlation matrix was constructed and is represented in Table 2.

It was decided to do a stepwise regression in an attempt to minimise any multicollinearity which might be present. The stepwise regression yielded the following equation:

$$
\begin{aligned}
\mathrm{Y}= & 61,84-20,34(\mathrm{LN} \text { Holding Period) }+ \text { 0,62(EBITDA } \\
& \text { CAGR) }+22,62(\mathrm{LN} \text { Earnings Multiple } \\
& \text { Extraction) }
\end{aligned}
$$

The R Squared was 53\%, which is weaker than R Squared of the multiple regression. However, the Adjusted RSquared was the same as that of the multiple regression at $49 \%$. Also note that the coefficients of EBITDA CAGR and Earnings Multiple Value Extraction were very similar to the coefficients derived under the multiple regression. 
Table 1: Multiple regression output

\begin{tabular}{|c|c|c|c|c|c|}
\hline Standard Error & 25.04859751 & & & & \\
\hline Observations & 46 & & & & \\
\hline \multicolumn{6}{|l|}{ ANOVA } \\
\hline & $d f$ & $S S$ & $M S$ & $F$ & Significance F \\
\hline \multirow{3}{*}{$\begin{array}{l}\text { Regression } \\
\text { Residual } \\
\text { Total } \\
\end{array}$} & 8 & 32063.74044 & 4007.967555 & 6.387889109 & $3.34865 \mathrm{E}-05$ \\
\hline & 37 & 23214.99278 & 627.4322373 & & \\
\hline & 45 & 55278.73322 & & & \\
\hline & Coefficients & Standard Error & t Stat & $P$-value & \\
\hline \multirow{5}{*}{$\begin{array}{l}\text { Intercept } \\
\text { LN Ownership } \\
\text { Debt } \\
\text { LN Holding Perio } \\
\text { EBITDA CAGR }\end{array}$} & 54.71683406 & 64.73877693 & 0.845194127 & 0.403435006 & \\
\hline & 13.23337741 & 15.31720332 & 0.863955197 & 0.393178948 & \\
\hline & -0.152065047 & 0.252842326 & -0.601422436 & 0.551226013 & \\
\hline & -13.73714379 & 10.90153101 & -1.260111426 & 0.215519090 & \\
\hline & 0.601310255 & 0.221647915 & 2.712907331 & 0.010062942 & \\
\hline \multirow{3}{*}{$\begin{array}{l}\text { LN Multiple Value Extraction } \\
\text { ST Interest Rates } \\
\text { LN Total Investment Cost }\end{array}$} & 22.25859051 & 5.642844887 & 3.94456891 & 0.000343129 & \\
\hline & -2.351982377 & 2.069123555 & -1.136704655 & 0.262970348 & \\
\hline & -18.39547618 & 12.22382003 & -1.504887681 & $\begin{array}{l}0.140842542 \\
\end{array}$ & \\
\hline
\end{tabular}

Table 2: Correlation matrix

\begin{tabular}{|c|c|c|c|c|c|c|c|c|}
\hline & $\begin{array}{c}\text { LN } \\
\text { Ownership }\end{array}$ & Debt & $\begin{array}{l}\text { LN Holding } \\
\text { Period }\end{array}$ & $\begin{array}{c}\text { EBITDA } \\
\text { CAGR }\end{array}$ & $\begin{array}{c}\text { LN Multiple } \\
\text { Value } \\
\text { Extraction }\end{array}$ & $\begin{array}{l}\text { ST Interest } \\
\text { Rates }\end{array}$ & $\begin{array}{l}\text { LN Total } \\
\text { Investment } \\
\text { Cost }\end{array}$ & $\begin{array}{c}\text { LN } \\
\text { Enterprise } \\
\text { Value }\end{array}$ \\
\hline LN Ownership & 10 & & & & & & & \\
\hline Debt & 01 & 10 & & & & & & \\
\hline LN Holding Period & 05 & -03 & 10 & & & & & \\
\hline EBITDA CAGR & -04 & -03 & -02 & 10 & & & & \\
\hline LN Multiple Value Extraction & 00 & 01 & -02 & -03 & 10 & & & \\
\hline ST Interest Rates & 02 & -03 & 06 & 00 & 00 & 10 & & \\
\hline LN Total Investment Cost & 03 & 00 & 02 & -01 & -03 & -01 & 10 & \\
\hline LN Enterprise Value & -01 & 01 & -01 & 00 & -03 & -03 & 09 & 10 \\
\hline
\end{tabular}

Each of the coefficients was tested for statistical significance. As revealed by the p-values in Table 1 , at the $5 \%$ significance level it was found that only the following variables' coefficients were significantly different from 0 under the multiple regression:

\section{- $\quad$ EBITDA CAGR}

- LN Earnings Multiple Value Extraction

Considering the stepwise regression, LN Holding Period was also found to be significantly different form 0 at the $5 \%$ significance level.

We will now discuss each of the independent variables used in the regression.

\section{Ownership}

Ownership refers to the percentage of shares owned by the general and limited partners collectively through whichever vehicles they might choose in the underlying investee company. For the purpose of this study, control is defined as an ownership stake of more than 50\%. Descriptive statistics revealed that the average level of ownership was $44 \%$ while the median was $34 \%$. Hence, it seems that on average, Private Equity managers do not tend to buy controlling stakes in the underlying investee companies. Looking at the scatter plot of the relationship between ownership and IRR
(Figure 1), it seems that there might be a negative relationship between the two. However, with a p-value of 0,39 there is almost no evidence to suggest that there is any relationship between the level of shareholding and the return achieved by the Private Equity manager. The analysis does not support the argument that managers achieve higher returns by having higher levels of ownership.

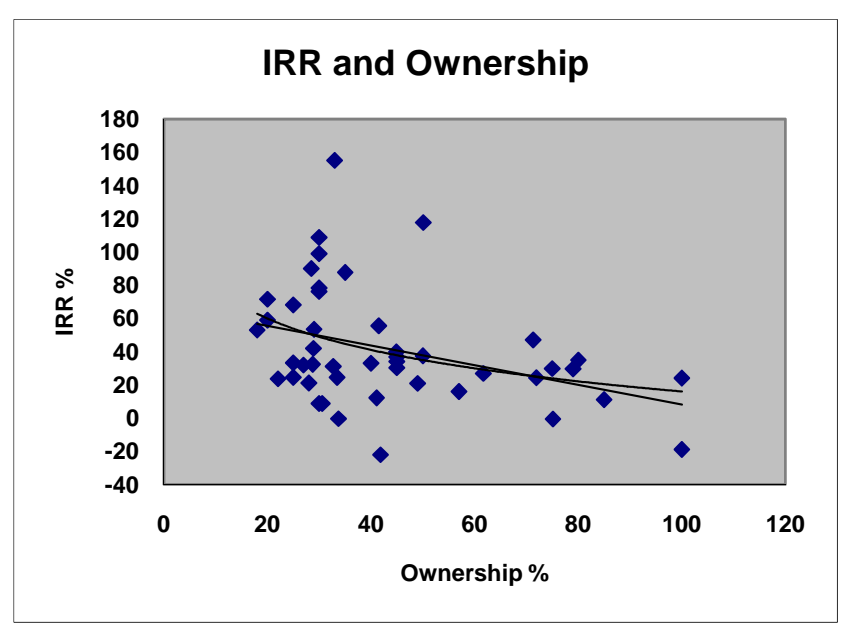

Figure 1: IRR and ownership scatter plot 


\section{Leverage}

The level of leverage had a p-value of 0,55 , suggesting there is no relationship between the debt employed and the returns on the investment.

An inspection of Figures 2 and 4 shows that one investment generated an IRR of $155 \%$ p.a. with $0 \%$ debt and an EBITDA CAGR of only 4,8\% p.a. On investigation it was found that the inception date of this investment in the technology sector was November 1995 and that the EBITDA multiple was 3,8. The investment was sold at the height of the technology boom in February 2000 at an EBITDA multiple of 21,7.

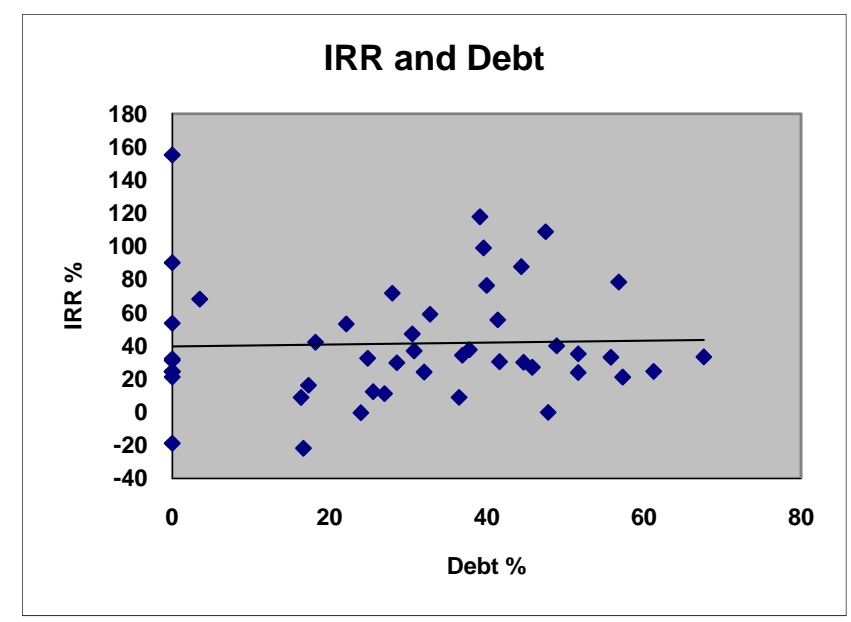

Figure 2: IRR and debt scatter plot

\section{Holding period}

The scatter plot in Figure 3 indicates a negative relationship between holding period and IRR. According to the p-value a negative relationship exists at the $22 \%$ level of significance under the multiple regression model. However, the stepwise regression revealed that a significant relationship between the Holding Period of investments and the IRR does indeed exist. This is consistent with the concept of early repayment in the Private Equity industry where earlier cash flows result in higher IRR's.

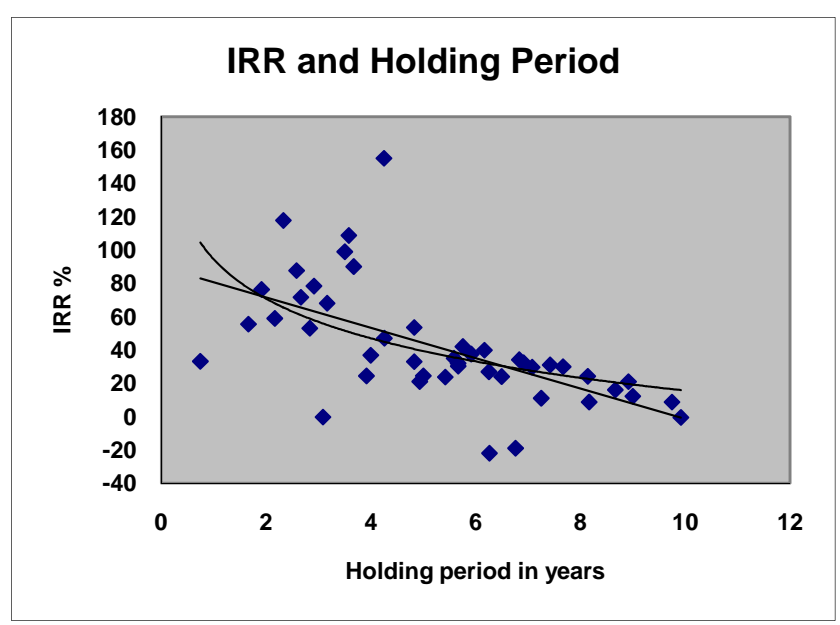

Figure 3: IRR and holding period scatter plot

\section{Earnings growth}

There was overwhelming evidence in the analysis to suggest that higher earnings growth leads to higher rates of return. Hence, the sample supports the findings that Private Equity managers strive to boost their returns by using methods at their disposal to increase the earnings of the investee company as a source of superior return.

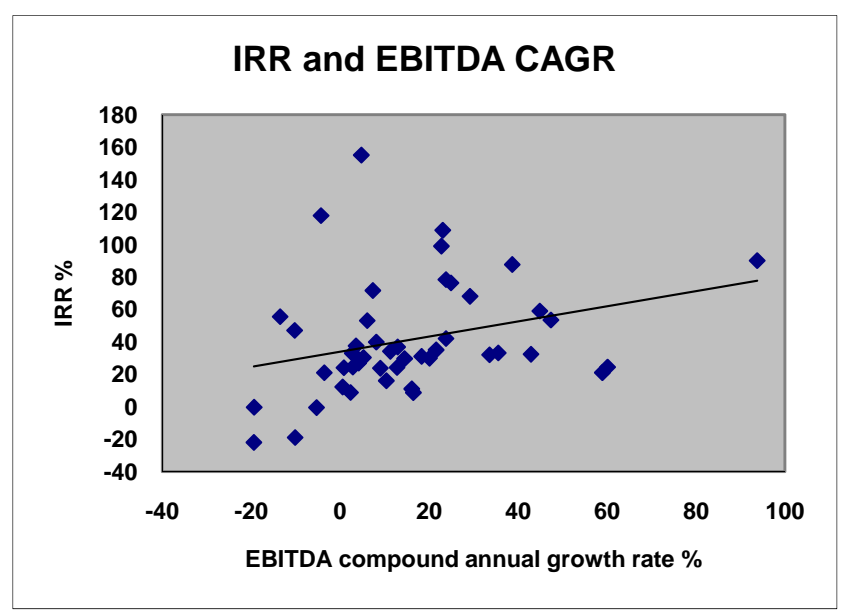

Figure 4: IRR and EBITDA CAGR scatter plot

\section{Earnings multiple increase}

According to the analysis the positive relationship between earnings multiple increases achieved by managers and the returns realised is almost $100 \%$. Some managers were able to buy at lower earnings multiples than the market, others were able to sell at higher earnings multiples than the market, and some were able to do both. It is evident that an increase in the earnings multiple is one of the most important sources of superior returns for Private Equity firms. Some proponents might question whether growth in the earnings multiple is not simply an alternative measure of success rather than a strategy for success. In such a case, Earnings Multiple Increase should be dropped as an independent variable and possibly be added as a dependent variable. Here one needs to consider the way in which Private Equity fund managers operate. They intentionally use their networks and negotiation skills to drive the purchase price as low as possible, and then explore several exit strategies such as listing on the stock exchange at high earnings multiples or actively marketing and negotiating a high exit price from a large pool of potential buyers. Hence, the authors are satisfied that this remains a key independent variable within the Private Equity domain. 


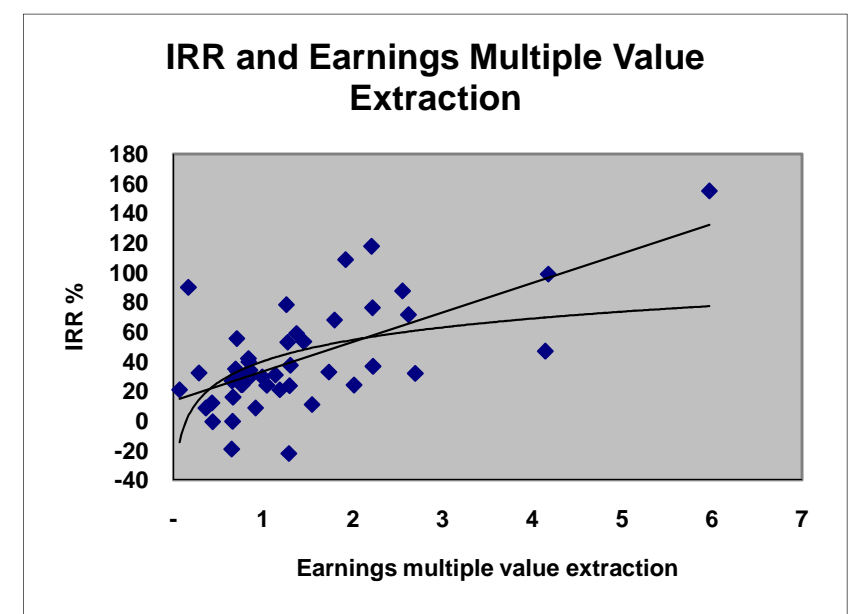

Figure 5: IRR and earnings multiple value extraction scatter plot

\section{Interest rates}

There is nothing to infer that a significant relationship exists between the IRR of an investment and the interest rate at entry of such investment.

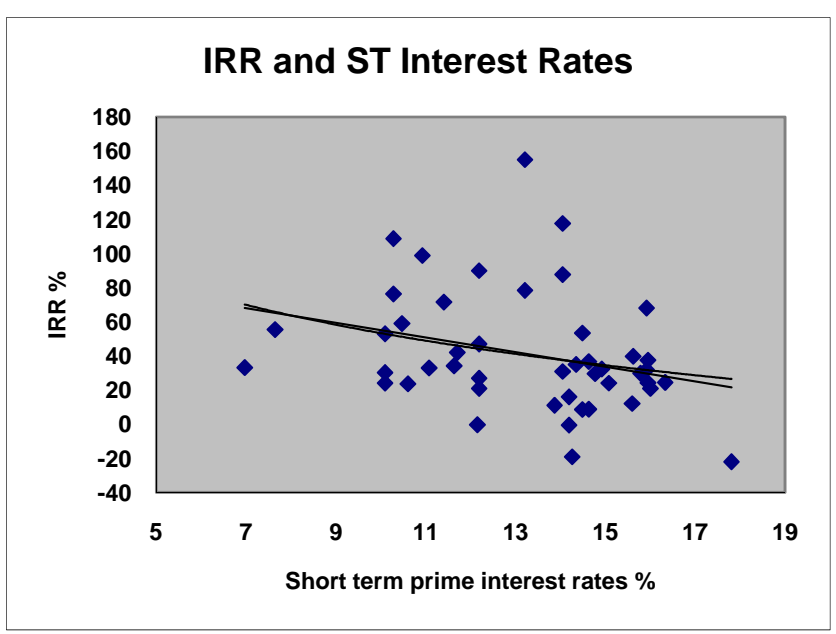

Figure 6: IRR and ST interest rates scatter plot

\section{Size of investment}

Although there was a tendency for a higher frequency of smaller investments, there was no evidence to suggest that a significant relationship exists between investment size and the returns achieved. Private Equity managers therefore did not seem to be concerned about investment size as having an effect on returns.

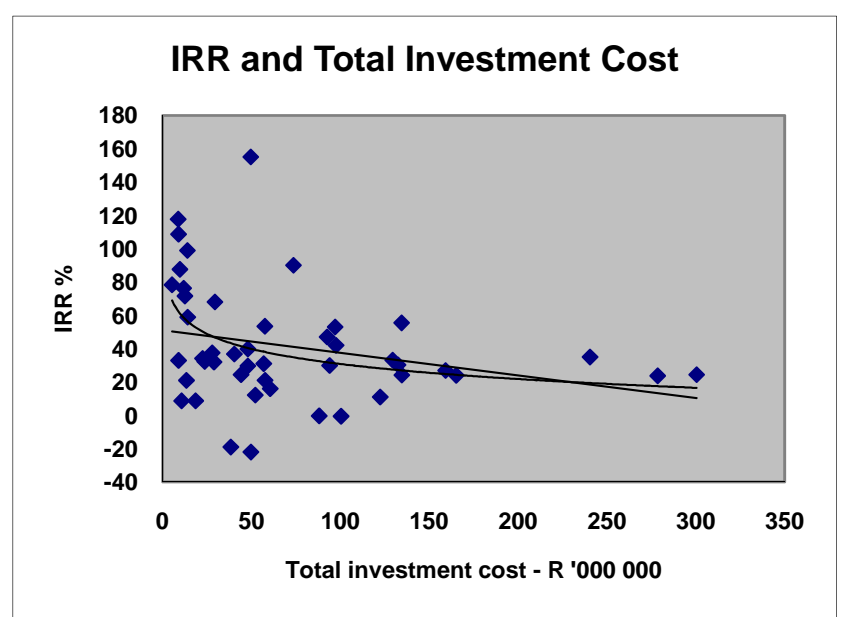

Figure 7: IRR and total investment cost scatter plot

\section{Conclusion}

The multiple regression done suggests that only earnings growth and earnings multiple increase displayed significant relationship with the returns achieved by the Private Equity managers on the investments included in the sample. Investors who would have bought the companies from the Private Equity firms usually place considerable emphasis on future cash flows when evaluating a company for investment. As higher earnings growth translates into higher future cash flow, it is obvious that Private Equity managers were able to sell companies with higher earnings growth potential at higher multiples. Hence, all the arguments can be reduced to one single source of superior return - earnings growth. Even so, the model's fit was not particularly convincing, explaining only $49 \%$ of the variability in the reported IRR's.

So how do Private Equity managers achieve their superior returns? Is the source of superior Private Equity returns like a type of Holy Grail which is ever-elusive? It is the view of the authors that the sources of superior Private Equity returns cannot be distilled in an empirical way. Private Equity investing is above all a highly specialised arena with a myriad of interdependent methods employed in order to take a business to a higher level and extracting the maximum from that investment. It is as much an art as it is a science. The individual techniques employed by managers to achieve superior returns will not be consistent, as every investment is unique and calls for an individualised approach. Herein lies the value-adding function of the Private Equity managers. They have the ability to assess each investment and each problem on its own merits in the ex-post management process, and then they use their superior knowledge, relationships, experience and exceptional management in an interrelated artful way to achieve a better outcome than their public market counterparts.

Relatively little research has been done on Private Equity in South Africa so far. The most comprehensive research on the topic is probably the paper by Missankov et al., (2006). There is ample opportunity for further research in the field. 
Much more research can be done to isolate the different factors contributing to IRR. It is noteworthy that such research could not been found by the authors in the international literature. The derivation of a model being able to compute the factor contributions seems to be the complex challenge. However, it would be interesting to see research where the contributions of earnings growth, earnings multiple growth, leverage, and cash flows are isolated. Another interesting extension of this study would be to test the explanatory power of the independent variables over a longer time period going forward by using the regression equation derived here.

Finally, this study suggests that Private Equity managers don't only extract short-term value from their investments, but that they actually sell much healthier and better companies than they bought in the first place. Research on the performance of South African Private Equity portfolio companies right after they were sold back into the public market compared with other public market benchmarks will shed informative light on this. Research done by Brooks, Ferreira and Harder (2002) might provide some insight into doing such an analysis.

\section{References}

Anson, M. 2007. 'Performance measurement in private equity: Another look', Journal of Private Equity, 10(3):721.

Barber, F. \& Goold, M. 2007. 'The strategic secret of private equity’, Harvard Business Review, 85(9):53-61.

Bent, N, Williams, K. \& Gilbert, E. 2004. 'The syndication of private equity investments in South Africa', South African Journal of Business Management, 35(4):39-48.

Boyer, C. \& Baigent, G. 2008. 'SPACs as alternative investments: An examination of performance and factors that drive prices', Journal of Private Equity, 11(3):8-15.

Brooks, L. D., Ferreira, E. J. \& Harder, J. T. 2002. 'Private equity offerings: Picking bad versus good performers', Journal of Private Equity, 5(3):57-62.

Cochrane, J. H. 2005. 'The risk and return of venture capital’, Journal of Financial Economics, 75: 3-52.

Dada, A. \& Thayser, D. 2007. 'Mergers and acquisitions driven by private equity, BEE and cross-border investment', Management Today, 23(3):61-62.

DeFusco, R. A., McLeavy, D. W., Pinto, J. E. \& Runkle, D. E. 2004. Quantitative methods for investment analysis. $2^{\text {nd }}$ Edition. Charlottesville: CFA Institute.

Deloitte. 2007. The South African Private Equity Confidence Survey, April. [online] URL: www.deloitte.com.

Ernst and Young. 2008. How do private equity investors create value? A global study of 2007 exits. London: Ernst \& Young.
Farzard, R., Goldstein, M., Henry, D. \& Palmeri, C. 2007. 'NOT SO SMART: In an era of easy money the pros forgot that the party can't last forever', Business Week, 03 September, p.30.

Fraser-Sampson, G. 2007. Private equity as an asset class. West Sussex: John Wiley \& Sons Ltd.

Gill, A. 2001. 'CG Watch: Corporate governance in emerging markets'. CLSA Emerging Markets unpublished paper, April.

Goldman Sachs Asset Management. 2007. Impact of the August credit crunch and implications for private equity. Goldman Sachs Asset Management Market Commentary, October.

Goldman Sachs Asset Management. 2008. Goldman Sachs 2007 Private Equity Diagnostic. Goldman Sachs Strategic Research, February.

Gompers, P., Kovner, A,. Lerner, J. \& Scharfstein, D. 2008. 'Venture capital investment cycles: The impact of public markets', Journal of Financial Economics, 87(1):1-23.

HarbourVest. 2008. Secondary allocations within private equity portfolios. White Paper. London: HarbourVest.

Kaplan, S. N. \& Schoar, A. 2005. 'Private equity performance: Returns, persistence, and capital flows', Journal of Finance, 60(4):1791-1823.

Kiechel, W. 2007. 'Private equity's long view', Harvard Business Review, 85(7/8), Jul/Aug:18-19.

KPMG \& SAVCA. 2008. 'Venture capital and private equity industry performance survey of South Africa covering the 2007 calendar year'. [online] URL: www.savca.co.za.

Ljungqvist, A. \& Richardson, M.P. 2003. 'The cash flow, return and risk characteristics of private equity'. Unpublished Working Paper. New York University.

Lockett, A. \& Wright, M. 2001. 'The syndication of venture capital investments', OMEG, The International Journal of Management Science, 29:375-390.

Millson, R. \& Ward, M. 2005. 'Corporate governance criteria as applied in private equity investments', South African Journal of Business Management, 36(1):73-85.

Missankov, I,. Van Dyk, R., Van Biljon, A., Hayes, M. \& Van der Veen, W. 2006. 'Is private equity a suitable investment for South African pension funds?' Paper presented at the Convention of the Actuarial Society of South Africa, October.

Moolenschot, S. 2002. 'Corporate governance in private equity investments'. M.B.A. Research Report. Johannesburg: University of the Witwatersrand. 
Rogers, P., Holland, T. \& Haas, D. 2002. 'Value acceleration: Lessons from private-equity masters', Harvard Business Review, 80(6):94-100.

Vanek, M. 2005. 'Is there still value in private equity?' Personal Finance Newsletter, 298 (September):8-10. 